\title{
ARTICLE \\ The Effect of 'Stabilization' in the Mandates and Practice of UN Peace Operations
}

\author{
Alexander Gilder ${ }^{1}[$ \\ Published online: 19 March 2019 \\ (c) The Author(s) 2019
}

\begin{abstract}
In the last decade UN peace operations have begun to explicitly seek 'stabilization' in the states to which they are deployed. Despite the term being included in the titles of four missions, three of which are amongst the four largest operations currently deployed, and stabilization activities being included in the mandates, there is no $\mathrm{UN}$-wide interpretation of the term. Instead, the mandates include varying activities under the heading of stabilization depending on the mission. Concurrently, stabilization missions have seen the use of language such as 'robust posture' and 'active patrolling', increased logistical capabilities from Western military hardware, the encroachment of a counter-terrorism rhetoric, operations alongside host state forces, and an emphasis on (re)establishing the rule of law. This article examines the legal effects these trends could have. Due to the competing interests introduced by stabilization it is suggested that the mandates issued by the UN Security Council require further clarity and harmonisation to prevent the pursuit of lasting peace from being undermined.
\end{abstract}

Keywords UN peacekeeping - Stabilization · Counter-terrorism · UN Security Council · International humanitarian law $\cdot$ Use of force $\cdot$ Responsibility of international organizations

\footnotetext{
The research for this article was completed in November 2018. Consequently, the article does not purport to reflect any more recent changes in the course of the conflicts discussed. All online resources were last accessed on 30 January 2019.
}

Alexander Gilder

Alexander.Gilder@city.ac.uk

1 The City Law School, City, University of London, London, UK 


\section{Introduction}

In recent years, stabilization has become entrenched in the United Nations (UN) Security Council's work on peace operations. ${ }^{1}$ However, the UN itself is yet to outline an organisation-wide understanding of the term. Missions in the Democratic Republic of Congo (DRC), Mali, and the Central African Republic (CAR) have linked the term with offensive force, 'robust' force, counter-terrorism, and increased cooperation with host state forces. However, stabilization has also led to UN attention on returning basic services, building the capacity of the host state to enforce the rule of law, and an inclusive peace process. Public international lawyers have seldom addressed the adoption of stabilization by peace operation mandates despite the potential legal effects and the overall trajectory of the international security system. In light of stabilization mandates, what is needed is to ascertain the next steps in developing mandates which are flexible yet consistent, respond to the needs of individuals in harm's way, but do not undermine the UN's ability to maintain international peace and security, and ensure adherence to humanitarian and human rights laws.

Current debates in academia and policy circles reflect a need to re-evaluate UN peacekeeping doctrine to assess the effect these doctrinal shifts have had in recent years. Instead of focusing on one issue, such as a robustness, this article fills a gap in recent stabilization discourse by taking a broader scope. Four elements of the missions that are evident after reviewing documentation on stabilization missions are set out below. Namely, the effect of 'robustness', counter-terrorism, cooperation with the host state, and the goal of entrenching the rule of law and ending impunity. These four elements reveal tensions which future mandates from the UN Security Council will need to rectify.

This article argues that if the UN wishes to engage in fighting an enemy alongside the host state and international forces then what needs to be addressed is harmonising the competing interests in the mandate to ensure the mission still seeks an inclusive peace process and effective national reconciliation. At the moment, stabilization mandates are fraught with risks that teeter between offensive and defensive force and could alter the legal footing of missions, particularly with regards to humanitarian law (IHL). The UN Security Council's current approach, where stabilization is used flippantly to mean a great number of mission activities depending on the mission context, risks undermining other areas of a mission's work and muddying the waters for the international community on what peace operations seek to achieve under the UN Security Council's responsibility to maintain international peace and security.

The article is based on an extensive review of UN documentation on the United Nations Multidimensional Integrated Stabilization Mission in Mali (MINUSMA)

\footnotetext{
1 This article typically uses the term 'peace operations' as opposed to 'peacekeeping'. 'Peace operations' is an inclusive term which encompasses a range of mission types. Peacekeeping is used in this article to denote a more traditional interpretation where there is peace to keep or where discussing the principles or doctrine of peacekeeping as distinct from peace enforcement.
} 
and the United Nations Multidimensional Integrated Stabilization Mission in the Central African Republic (MINUSCA) and thus mainly derives examples from those missions. First, the definitions of stabilization used by the United Kingdom (UK) and United States (US) are outlined. A blending of these two definitions reveals the UN's current usage of the strategy. ${ }^{2}$ Second, the four key aspects of stabilization mentioned above are discussed drawing on examples from MINUSMA, MINUSCA, and the United Nations Organization Stabilization Mission in the Democratic Republic of the Congo (MONUSCO). While it is arguably positive that the UN recognises the need to take proactive, preventative steps to minimise harm to civilians, there are nevertheless tensions visible in the current mandates. It is discussed below how 'robust' force toes a fine line between peacekeeping and peace enforcement that risks the missions becoming a party to conflicts under IHL. In addition, the UN's increased concern with counter-terrorism is an activity the UN is ill-prepared for and could entangle the organisation in protracted conflicts against an elusive enemy. Cooperation with the host state presents the prospect that the UN could be deemed responsible for aiding internationally wrongful acts committed by host state forces and further compounds the risk that the local population could lose trust in the traditionally impartial UN personnel. The final key area of stabilization mandates, advancing the rule of law and ending impunity, holds prospects for building a lasting peace but could be detrimentally affected by a counter-terrorism rhetoric or increased war-fighting.

\section{What Does Stabilization Mean?}

The last decade has seen a seismic shift in how UN peace operations are mandated and the situations to which they are deployed. In the 2000s the majority of peacekeepers were utilised in post-conflict situations where a peace agreement was in place. Conversely, two-thirds of peacekeepers in 2015 were deployed to ongoing conflicts. ${ }^{3}$ Doctrinally however, there have been no major internal policy re-evaluations of peace operations similar to the Capstone Doctrine in 2008 to review and document the shifts in practice. What is evident though is that operations in recent years have been given more robust mandates where force is used to pursue the goal of stabilization. ${ }^{4}$ This section does not purport to provide a comprehensive definition of stabilization. Instead, the section looks at how stabilization has been interpreted by two permanent members of the UN Security Council and how the concept is portrayed in academia. The section gives the necessary background before the article turns to analyse the risks associated with stabilization.

In 2015 the Report of the High-Level Independent Panel on Peace Operations (HIPPO) stated, '[t]he term "stabilization" has a wide range of interpretations, and the Panel believes the usage of that term by the United Nations requires

\footnotetext{
${ }^{2}$ Curran and Holtom (2015), pp. 3, 4.

3 De Coning (2015), p. 18; see also Peter (2015).

${ }^{4}$ Karlsrud (2017a), p. 3.
} 
clarification'. 5 Some UN officials say that no specific significance should be given to the fact that some missions have been designated 'stabilization' missions. ${ }^{6}$ The UN has not formally adopted a definition of the term or clear policy guidelines on what activities a stabilization mission will entail. In fact, the operations that use the term stabilization have a range of different activities in their mandates. The adoption of stabilization has been said to be a 'hodge-podge' of words and '[t]he danger is that the terminological imprecision surrounding "stabilization" creates a meta-category; full of buzzwords but empty of meaning'.

With no agreement on the topic at the UN it is necessary to look at the states influencing the UN Security Council's decision-making process which arguably underpins this turn to stabilization. Two members of the P5 have developed a deeper understanding of stabilization, namely the UK and US, and it has been argued that a shared understanding exists between NATO states. ${ }^{8}$ The adoption of stabilization policies by the UK and US is important due to the fact that the UK, US, and France (the so-called P3) have become pen-holders on most resolutions relating to UN peace operations and these countries have shared 'stabilization' experiences from the conflicts in Iraq and Afghanistan. ${ }^{9}$

The UK Stabilisation Unit informs its deployees to UN missions that it is common to find there is no shared and coordinated vision of stabilization. ${ }^{10}$ The UK Stabilisation Unit defines stabilisation as an approach,

...which is designed to protect and promote legitimate political authority, using a combination of integrated civilian and military actions to reduce violence, re-establish security and prepare for longer-term recovery by building an enabling environment for structural stability. ${ }^{11}$

The use of an integrated approach seeking long-term recovery is similar to that of other twenty-first century operations. However, a core difference is the identification of a legitimate authority which has traditionally been avoided in peace operations. The UK Stabilisation Unit further stresses that in a destabilised state there will likely be a number of parties vying for control through force. ${ }^{12}$ As a result, a decision will need to be taken with regard to who with and how to work in the environment. Actors engaged in stabilization will necessarily need to determine who the legitimate authority is they wish to give support with care and attention to ensuring

\footnotetext{
${ }^{5}$ UN Security Council and UN General Assembly, 'Identical letters dated 17 June 2015 from the Secretary-General addressed to the President of the General Assembly and the President of the Security Council' (17 June 2015), A/70/95-S/2015/446, para. 114.

6 De Coning (2018), p. 87.

7 Mac Ginty (2012), p. 24.

8 Curran and Holtom (2015), p. 3.

9 De Coning (2018), p. 87.

${ }^{10}$ UK Stabilisation Unit, 'Working in United Nations Missions: Deployee Guide' (October 2014), http:// www.sclr.stabilisationunit.gov.uk/publications/deployee-guide-series/492-deployee-guide-un/file, p. 23.

11 UK Stabilisation Unit, 'The UK Government's Approach to Stabilisation (2014)' (May 2014), http:// sclr.stabilisationunit.gov.uk/publications/stabilisation-series/487-uk-approach-to-stabilisation-2014, p. 2.

12 Ibid., p. 2.
} 
the legitimate authority is a 'locally and/or nationally-owned and led authority'. ${ }^{13}$ The UK focuses on a 'comprehensive approach' to stabilization which is civilian-led with the support of the military. ${ }^{14}$

The US takes a narrower approach to stabilization where it is understood the intervening force defeats an insurgency while at the same time entrenching support for a domestically owned transition towards peace and the capacity building of society to be resilient to the causes of conflict. ${ }^{15}$ Under this approach, the goal of stabilization is to support the legitimate authority in securing the monopoly on the use of force to enable the authority to protect its population. ${ }^{16}$ The similarities between the approaches are the identification of a legitimate authority and the capacity building of the authority to be able to deflect spoilers to peace. The use of force in this manner, to counter spoilers in support of a legitimate authority, typically the host state, has been described as 'bordering on counterinsurgency'. ${ }^{17}$

UN missions that include 'stabilization' in their title typically include a number of shared hallmarks in their mandates that are similar to the two approaches above. First, they are mandated to support the extension of state authority. ${ }^{18}$ Second, they operate alongside state forces and actively build the capacity of those forces. ${ }^{19}$ Third, they use varying degrees of proactive, 'robust' force to prevent attacks on themselves and those they are mandated to protect. ${ }^{20}$ Lastly, they have mandates to support (re)establishing the rule of law. ${ }^{21}$ These similarities though have not yet been formulated into an UN-wide understanding of stabilization. Within academia it has been postulated that there is a distinct trend of stabilization missions being asked to contain aggressors, enforce law and order, and protect civilians. ${ }^{22}$ Furthermore, it has been argued by Curran and Holtom that the UN's approach to stabilization is a marrying of the UK and US understandings of the concept. ${ }^{23}$ That is to say (a) force is used to deter or displace armed groups following the US interpretation and (b) civilian led peacebuilding activities, aimed at entrenching the rule of law and re-establishing the state as the legitimate authority, take place in the power vacuum

\footnotetext{
13 Ibid., p. 3.

14 Curran and Holtom (2015), pp. 3, 4; see also, Gordon (2010), p. S370.

15 Gordon (2010), p. S372.

16 US Joint Chiefs of Staff, 'Joint Publication 3-07 Stability Operations' (29 September 2011), https:// health.mil/Reference-Center/Policies/2012/07/16/Joint-Pub-307-Stability-Operations-September-292011, p. xvi.

17 Curran and Holtom (2015), p. 4.

18 See e.g. UN Security Council, Resolution 2423 (28 June 2018), S/RES/2423, paras. 38(a)(i), 38(b); UN Security Council, Resolution 2364 (29 June 2017), S/RES/2364, para. 20(a)(i); UN Security Council, Resolution 2387 (15 November 2017), S/RES/2387, para. 43(a); UN Security Council, Resolution 2301 (26 July 2016), S/RES/2301, para. 34(a)(i).

19 S/RES/2423 (n. 18), para. 38(b); S/RES/2364 (n. 18), para. 20(a)(ii); S/RES/2387 (n. 18), para. 43(a) (iv); S/RES/2301 (n. 18), para. 34(a)(v).

20 S/RES/2423 (n. 18), paras. 33, 34; S/RES/2364 (n. 18), para. 20(c)(ii); S/RES/2387 (n. 18), para. 42(a)(ii); S/RES/2301 (n. 18), para. 34.

21 S/RES/2423 (n. 18), para. 38(a)(i); S/RES/2364 (n. 18), para. 20(a)(ii); S/RES/2387 (n. 18), para. 43(e); S/RES/2301 (n. 18), para. 34(d).

22 De Coning (2018), p. 92.

23 Curran and Holtom (2015).
} 
left behind. ${ }^{24}$ As will be discussed below there are potential legal issues where UN forces engage in these activities.

\section{Implications for Peacekeeping Doctrine and Future Mandates}

\subsection{The 'Robust' Use of Force: Offence or Defence?}

As has just been mentioned the mandates of UN stabilization missions include the 'robust' use of force. This section explains how 'robust' actions both toe a fine line between peacekeeping and peace enforcement, and risk UN forces becoming a party to the conflict under IHL. The examples below demonstrate how it can be increasingly difficult to determine where defence becomes offence. In recent years, mandates have typically authorised force in defence of the mandate under Chapter VII of the UN Charter. However, robustness strays toward taking the initiative in the use of force which is indicative of peace enforcement. While peace enforcement is permitted under Chapter VII and does not violate international law, the UN needs to clarify the course which peacekeeping operations are currently plotting as there can be consequences in international humanitarian law for both the troops and UN as a whole. Traditionally peacekeepers would 'never take the initiative in the use of armed force' and only respond in self-defence. ${ }^{25}$ In situations where UN forces are no longer acting in self-defence and are engaging an enemy to 'silence sources of deadly fire' the UN could be deemed a party to the conflict and bound by IHL. ${ }^{26}$

\subsubsection{Mission Specific Examples of 'Robustness'}

In March 2013 MONUSCO was given a Force Intervention Brigade (FIB) which was the first UN blue helmet offensive combat force. ${ }^{27}$ The FIB was originally made up of 3069 soldiers mandated 'to prevent the expansion of all armed groups, neutralize these groups, and to disarm them in order to contribute to the objective of reducing the threat posed by armed groups on state authority and civilian security'. ${ }^{28}$ The FIB would carry out its activities unilaterally or jointly with the Congolese army (FARDC) 'in a robust, highly mobile and versatile manner'. ${ }^{29}$ Therefore, the FIB would be partial and expressly take sides in the conflict between a state and armed groups affirming the state as the legitimate authority. The UN understood the FIB to

\footnotetext{
24 Tull (2018), p. 186.

25 UN Secretary-General, 'Summary of the experiences derived from the establishment and operation of the force' (9 October 1958), A/3943, para. 179.

26 Sloan (2018), p. 276.

27 UN Security Council, Resolution 2098 (28 March 2013), para. 9; Patrick Cammaert and Fiona Blyth, 'Issue Brief: The UN Intervention Brigade in the Democratic Republic of the Congo' (International Peace Institute, July 2013), https://reliefweb.int/sites/reliefweb.int/files/resources/The\%20UN\%20Int ervention\%20Brigade\%20in\%20the\%20Democratic\%20Republic\%20of\%20the\%20Congo.pdf, p. 2.

28 S/RES/2098 (n. 27), para. 12.

29 Ibid., para. 12.
} 
be a peace enforcement mission and not a peacekeeping one due to its use of not just robust force but going further into offensive action. ${ }^{30}$

Conversely, MINUSCA and MINUSMA are not defined as peace enforcement missions and have not used offensive force in a similar fashion to the FIB in the DRC but the mandates make use of similar wording; to extend state authority and stabilise population centres which is achieved through actions such as a 'robust posture' and active patrolling to deter armed groups and allow space for the restoration of state authorities. ${ }^{31}$ Looking at MINUSCA first, in February 2017 the mission launched Operation Bekpa to stabilise the town of Bambari by securing the agreement that the armed groups would leave. MINUSCA used armed helicopters to engage armed groups attempting to re-enter the town. ${ }^{32}$ Lieutenant General Keita reported to the UN Security Council that the 'operation succeeded because we bent various administrative rules, challenged some limiting agreements with troops and changed morale where the use of force was involved'. ${ }^{33}$ MINUSCA has further undertaken robust operations to 'expel' the Front démocratique group from roads between Baboua and Beloko. ${ }^{34}$ More recently, a 'joint disarmament and arrest operation' alongside the CAR armed forces (FACA) was launched against criminal groups in Bangui's PK5 neighbourhood where MINUSCA participated in armed raids which led to exchanges of fire and the death of a peacekeeper. ${ }^{35}$ In the month following the armed raids, the UN Independent Expert on the situation of human rights in the Central African Republic, Marie-Thérèse Keita Bocoum, called for a strategy on the 'neutralisation' of armed groups in the CAR. ${ }^{36}$ Thus far, the 'neutralisation' of armed groups has not been included in MINUSCA's mandate to denote similar offensive force to MONUSCO's FIB.

Turning to MINUSMA, the mission has contingents of forces from Western countries and sophisticated military hardware including short range drones, and

\footnotetext{
30 See above, Cammaert and Blyth (n. 27).

31 UN Security Council, 'Report of the Secretary-General on the Central African Republic' (2 June 2017), S/2017/473, para. 2; S/RES/2301 (n. 18), paras. 34, 34(a); S/RES/2364 (n. 18), para. 19; UN Security Council, Resolution 2164 (25 June 2014), S/RES/2164, para. 13(a)(i).

32 S/2017/473 (n. 31), para. 11; UN Security Council, 7947th Meeting (23 May 2017), S/PV.7947, p. 12 as per Mr. Barro.

33 S/PV.7947 (n. 32), p. 8 as per Lieutenant General Keïta.

34 UN Security Council, 'Report of the Secretary-General on the situation in the Central African Republic' (29 July 2015), S/2015/576, para. 23.

35 UN Security Council, 'Situation in the Central African Republic' (18 June 2018), S/2018/611, paras. 16, 17; MINUSCA, 'Central African Forces and MINUSCA launch a disarmament and arrest operation against armed criminals in Bangui's PK5 neighborhood' (Press Release, 8 April 2018), https://minus ca.unmissions.org/en/central-african-forces-and-minusca-launch-disarmament-and-arrest-operationagainst-armed-criminals; MINUSCA, 'MINUSCA condemns fresh attack against peacekeepers in Bangui' (Press Release, 10 April 2018), https://minusca.unmissions.org/en/minusca-condemns-fresh-attac k-against-peacekeepers-bangui.

36 MINUSCA, 'UN expert calls for calm, protection of civilians in Central African Republic' (3 May 2018), https://minusca.unmissions.org/en/un-expert-calls-calm-protection-civilians-central-african-repub lic.
} 
attack and transport helicopters. ${ }^{37}$ MINUSMA has aimed to 'progressively dominate areas adjacent to population centres' to prevent access to terrorist groups and criminals. ${ }^{38}$ In 2016 the UN Security Council called for MINUSMA to engage in direct operations against asymmetric threats. ${ }^{39}$ Tull believes this step by the UN Security Council is not 'clear-cut' peace enforcement but is midway between so-called robust peacekeeping and enforcement through offensive force. ${ }^{40}$ MINUSMA has carried out operations 'to neutralize threats, targeting improvised explosive devices', area and axis control of main supply routes to identify and arrest terrorists, and conducted patrols with the support of attack helicopters. ${ }^{41}$

Considering in particular the joint disarmament and arrest operation in Bangui, is it clear where UN forces have used defensive rather than offensive force? The joint disarmament and arrest operation can, on the one hand be viewed as the UN taking the initiative in using force and taking an offensive footing to both deter future perpetrators and neutralise the existing threat to civilians. On the other hand, it could be said that MINUSCA is operating in defence of the mandate since the mandate provides for MINUSCA to take urgent temporary measures allowing the mission 'to arrest and detain in order to maintain basic law and order and fight impunity'. ${ }^{42}$ The question then becomes whether these urgent temporary measures allow the offensive use of force when pursing basic law and order? The mandate specifically states the temporary measures are adopted 'without prejudice to the agreed principles of peacekeeping operations' which would indicate that force is to be used in defence of the mandate. ${ }^{43}$ The terminology though is troubling. Where UN forces leave their base with the intention of using force to exact armed raids and, in the event, exchange fire, it is difficult to maintain that the action is purely defensive.

Similarly, the call for MINUSMA to engage in 'direct operations' is not a clear authorisation to use offensive force but does, at least, raise the question as to whether it authorises the mission to take the initiative in using force to combat threats to civilians. As a result, there is a visible wavering between a 'robust posture' and enforcement activity. Despite the UN Security Council stating this posture is without prejudice to the principles of peacekeeping the underlying doctrine of peace operations comes into question where proactive steps are increasingly taken by UN forces. $^{44}$

\footnotetext{
${ }^{37}$ Karlsrud (2015), p. 47; Boutellis (2015), p. 8; for further examples of the intelligence equipment available to MINUSMA see de Cherisey (2017).

${ }^{38}$ UN Security Council, 'Report of the Secretary-General on the situation in Mali' (9 June 2014), S/2014/403, para. 66 .

${ }^{39}$ UN Security Council, Resolution 2295 (29 June 2016), S/RES/2295.

40 Tull (2018), p. 168.

${ }^{41}$ S/RES/2295 (n. 39), para. 16; UN Security Council, 'Report of the Secretary-General on the situation in Mali' (29 September 2016), S/2016/819, paras. 32, 38.

${ }^{42}$ S/RES/2387 (n. 18), para. 43(e)(iii).

${ }^{43}$ Ibid., para. 43(e)(iii).

${ }^{44}$ Ibid., para. 39.
} 


\subsubsection{Is Robustness Peacekeeping or Peace Enforcement?}

UN peace operations have previously been said to operate under 'Chapter VI and a half'. Traditional peacekeeping was conducted under Article 36(1) of the UN Charter (Chapter VI) and UN forces would deploy with the consent of the host state and only use force in self-defence. Today's operations, which go beyond the separation of warring parties and monitoring of peace agreements, are typically authorised under Chapter VII to use force and as a result are a blend of Articles 40 and 42 depending on whether the UN forces are enforcing provisional measures or 'taking all necessary measures' to ensure the realisation of other mandated activities such as the protection of civilians. Alongside the Chapter VII mandate, UN forces will pursue traditional Chapter VI activities such as monitoring a peace agreement. Importantly though, modern UN peace operations that use force under Chapter VII do adhere, on some level, to the principles of consent, impartiality, and an altered interpretation of where they may use force, namely to protect themselves, persons they are mandated to protect, and the mission's ability to achieve its mandate. ${ }^{45}$

Enforcement under Chapter VII has, in the past, been undertaken by coalitions of the willing whom operate under UN Security Council authorisation but do not constitute UN-mandated peace operations. The robust use of force by peacekeepers and the inception of the FIB has obscured the distinction between traditional peacekeepers who use force in self-defence and those who can be more proactive under Chapter VII mandates, straying toward a more liberal use of force.

Most operations using robust force are not conducting 'full-blown' enforcement action under Chapter VII and do operate with the 'consent, or at the least acquiescence, of all the parties to the conflict or dispute' ${ }^{46}$ This is because robust force includes using force at the tactical level 'to defend its mandate against spoilers whose activities pose a threat to civilians or risk undermining the peace process' whereas peace enforcement allows the use of force at the strategic or international levels. ${ }^{47}$ By using force at the strategic and international levels, actions are taken in

\footnotetext{
${ }^{45}$ De Coning (2017), p. 147; UN, United Nations Peacekeeping Operations: Principles and Guidelines (UNDPKO 2008) (the 'Capstone Doctrine'), http://www.un.org/en/peacekeeping/documents/capstone eng.pdf, p. 34.

46 Gill and Fleck (2015), p. 154.

${ }^{47}$ Capstone Doctrine (n. 45), p. 98, Bellamy and Hunt (2015), p. 1281; the Capstone Doctrine has been described as a move towards the robust use of force indicating a shift away from the traditional interpretation of self-defence. See e.g. Gerchicoff (2013), p. 733. Mandates include strategic, operational and tactical goals and activities. The Security Council, Secretary-General and Secretariat occupy the strategic level giving legal authority and high-level direction and guidance. The operational level is the field-based management of a peace operation by Mission Headquarters comprising, the Head of Mission, Head of Military and Police components (HOMC and HOPC), Deputy Special Representative(s) of the SecretaryGeneral (DSRSG), and Director of Mission Support/Chief of Mission Support (DMS/CMS). The tactical level is the management of military, police, and civilian operations below Mission Headquarters where supervision is given by subordinate commanders. See UNDPKO, 'Authority, Command and Control in United Nations Peacekeeping Operations' (Ref. 2008.4, February 2008).
} 
excess of self-defence and both the use and threat of force are deemed to be 'acceptable methods of persuasion-not measures of last resort'. ${ }^{48}$

For instance, the FIB operates under an enforcement mandate where force is used at the strategic level alongside the host state military. ${ }^{49}$ The FIB does not only use force in self-defence. Instead there is an assumption that the FIB will use force proactively to neutralise targets. Due to the relationship with the host state, the FIB consequently acts in a partial matter where it has taken a side in the conflict and identified an aggressor, which it uses offensive force to combat. ${ }^{50}$

By using the interpretation that robust force means using force in defence of the mandate those operations are not perceived to have veered into peace enforcement as a whole and instead remain peacekeeping operations. However, there is debate on whether certain robust actions taken under mandates that utilise 'robust' force constitute enforcement action under Article 42. ${ }^{51}$ Actions such as the arrest operation in the PK5 neighbourhood are likely carried out under the authorisation to use force in the defence of the mandate and to protect civilians. ${ }^{52}$ However, it has previously been argued that 'allowing peacekeepers to use force in defence of the mandate simply introduces the use of offensive force through the back door'. ${ }^{53}$ The question then becomes, at what point does defence become offence? Using force in defence of the mandate is a catch all phrase which allows a peace operation to take the initiative. Taking the initiative risks becoming synonymous with offensive force if operations regularly take direct actions against asymmetric threats, perform disarmament and arrest operations or other actions where peacekeepers seek out threats to the peace process.

\subsubsection{Can Robust Force Make the UN a Party to the Conflict under IHL?}

The default status of a peacekeeper is as a non-combatant, but the status can be subject to change with the peacekeeper classified as a combatant if they actively engage in the armed conflict and the intensity threshold is met. ${ }^{54}$ The robust use of force has sparked a debate as to when and who become parties to the conflict when fighting intensifies between UN troops and armed groups. The UN Office of

\footnotetext{
48 Patryk I. Labuda, 'Peacekeeping and Peace Enforcement' (Max Planck Encyclopedia of Public International Law, September 2015), para. 34.

49 Cammaert and Blyth (n. 27), p. 6; See also, Tull (2018), p. 185.

50 De Coning (2017), p. 148. See also, Berdal (2018).

51 See e.g. Tardy (2011).

52 It is interesting to note that the PK5 operation is one of law enforcement targeting criminal gangs. Under the mandate at the time, Resolution 2387, MINUSCA's urgent temporary measures to arrest and detain persons to maintain basic law and order are explicitly to be used 'where national security forces are not present or operational'. The operation was carried out alongside CAR forces which must mean MINUSCA believed it could instead act under its protection of civilians mandate. See S/RES/2387 (n. 18), para. 42(e)(iii).

53 Pacholska (2015), p. 51.

54 White (2015), p. 52; UN Secretary General, 'UN Secretary General's Bulletin, Observance by UN Forces of International Humanitarian Law' (6 August 1999), UN Doc. ST/SGB/1999/13; Gill et al. (2017), p. 95; Foley (2017), p. 140.
} 
Legal Affairs previously stated with regards to the United Nations Protection Force (UNPROFOR) that UN forces are not under an obligation to uphold the Geneva Conventions since the treaty obligations of humanitarian law are only applicable to states. ${ }^{55}$ Domestic courts took similar views, such as in Canada where it was said humanitarian law does not apply to peace operations and in Belgium where it was found humanitarian law did not apply to Belgian troops in Somalia and Rwanda. ${ }^{56}$ The UN has also claimed it cannot be a 'party' to or a 'High Contracting Power' in an armed conflict under the Geneva Conventions. ${ }^{57}$ Although in 1999 the Secretary General issued a bulletin outlining that UN forces would observe IHL where they are actively engaged as combatants. ${ }^{58}$

In 2015, the HIPPO Report stressed that when UN operations stray into enforcement actions, they must be carried out with full respect for humanitarian law and that such actions "may make the United Nations forces, and the mission as a whole, a party to the conflict... ${ }^{59}$ Invariably this raises two points. First, the HIPPO Report has raised the possibility that, in fact, the UN could be a party to the conflict despite not being a 'High Contracting Power' and not having the juridical and administrative frameworks in place to meet the obligations found in the Geneva Conventions. ${ }^{60}$ Second, the HIPPO Report did not address the issue of when the robust use of force could result in the mission becoming a party to the conflict.

Whether the UN is a party to the conflict is particularly relevant where peacekeepers are undertaking operations alongside host state forces. In such a situation it may be the case that the host state forces are a party to the conflict, but the UN mission is not. MINUSMA and MINUSCA are both deployed to theatres of operation where a non-international armed conflict exists (NIAC). For the existence of a NIAC there needs to be armed violence of sufficient intensity and the parties need to be sufficiently organised. ${ }^{61}$ In determining whether a peace operation has become a party to a NIAC there needs to be consideration of the mandate, the rules of engagement, the nature of the equipment used, the nature of and frequency of force used between the parties, and the conduct of personnel. ${ }^{62}$

For example, in MONUSCO the FIB operations to neutralise armed groups were carried out using heavy weapons and in concert with FARDC. The question was

\footnotetext{
55 Murphy (2007), p. 247.

56 Ibid., pp. 273-276; Her Majesty the Queen v. Private DJ Brocklebank, [1996] Court Martial Appeal Court of Canada, Court File No. CMAC-383; Judgment of the Belgian Military Court regarding violations of IHL committed in Somalia and Rwanda (20 November 1997), Nr 54 AR 1997.

57 Murphy (2007), p. 215.

58 ST/SGB/1999/13 (n. 54).

59 HIPPO Report (n. 5), para. 122.

60 Murphy (2007), p. 248; the International Committee of the Red Cross (ICRC) have stressed that where UN peace operations take persons into detention they must be able to meet their legal obligations and that 'detention related activities of missions remain underfunded with limited capacities in terms of logistics, infrastructure and trained human resources'. ICRC, 'Peacekeeping operations: ICRC statement to the United Nations, 2017' (27 October 2017), https://www.icrc.org/en/document/peacekeeping-opera tions-icrc-statement-united-nations-2017.

61 Gill et al. (2017), p. 94

62 Ibid., p. 95.
} 
whether the entire operation had become a party to a NIAC or not? Some members of the UN Security Council argued that there was a distinction to be drawn where the FIB could be regarded as a party to the conflict but that the rest of MONUSCO was not. ${ }^{63}$ The Convention on the Safety of United Nations and Associated Personnel, which outlines the protections afforded to UN peacekeepers, specifies that the provisions do not apply to an operation authorised as an enforcement action. ${ }^{64}$ As has been discussed above, stabilization missions are not expressly mandated as enforcement actions but have stronger mandates to engage armed groups. This leaves a grey area of when those peacekeepers become a party to the conflict if hostilities intensify.

Looking at Mali in particular, if it is accepted that there is a NIAC between the state and various terrorist groups operating in the north of the country it becomes important to consider whether MINUSMA is a party to that NIAC. As discussed above, MINUSMA has been mandated to engage in 'direct operations' and it has been supported by sophisticated military hardware such as short-range drones and attack helicopters. ${ }^{65}$ In addition, the most recent mandate renewal in 2018 specifies that MINUSMA is to conduct joint operations and share information with the Malian Defence and Security Forces (MDSF). ${ }^{66}$ Peace operations do not typically fight a war against an enemy and will usually use force sporadically. ${ }^{67}$ Instead peace operations often provide logistical support and intelligence for the host state. Where providing support the ICRC argues UN forces can be deemed a party to a pre-existing NIAC under the following circumstances;

(1) there is a pre-existing NIAC taking place on the territory in which multinational forces are called on to intervene; (2) actions related to the conduct of hostilities are undertaken by multinational forces in the context of the preexisting conflict; (3) the military operations of multinational forces are carried out in support (as described above) of a party to the pre-existing conflict; and (4) the action in question is undertaken pursuant to an official decision by the troop-contributing country or the relevant organization to support a party involved in the pre-existing conflict. ${ }^{68}$

The ICRC claims that meeting these criteria displays a 'genuine belligerent intent' which would result in participation in hostilities. ${ }^{69}$ Nevertheless, the UN Assistant Secretary-General for Legal Affairs, Stephen Mathias, has said that even where there are not direct armed clashes with spoilers it is unclear whether support for the host state alone would make the UN mission a party to the conflict. ${ }^{70}$

\footnotetext{
63 Mathias (2017), p. 143.

64 The Convention on the Safety of United Nations and Associated Personnel, Art. 2(2).

65 De Cherisey (2017).

66 S/RES/2423 (n. 18), para. 38(b).

67 ICRC, 'International Humanitarian Law and the Challenges of Contemporary Armed Conflicts' (32nd International Conference of the Red Cross and Red Crescent, 8-10 December 2015), p. 22.

68 Ibid., p. 23.

69 Ibid., p. 23.

70 Mathias (2017), p. 143. NB comments were made in a personal capacity.
} 
Stabilization missions are seemingly combining both (1) support for the host state military capacities with (2) a more robust posture that could result in an intensification of hostilities. Even if the UN do not accept that providing logistical support and intelligence makes the mission a party to the conflict, the fact that MINUSMA is conducting joint operations, is supported by attack helicopters and drones, and have had skirmishes with armed groups, make the intensification of hostilities a distinct possibility. Where there are sustained, direct clashes between MINUSMA and armed groups it would be difficult for the UN to contest the applicability of IHL. In this situation then a mandate to use robust force can lay the groundwork for UN forces to more frequently engage in clashes and also carve a larger role for the UN in the provision of military support to a host state.

It is important to note that the consequence of becoming a party to the conflict, or participation in hostilities, is that UN peacekeepers would lose their non-combatant status and could legally be targeted by armed groups. Whereas, where the UN mission is not a party or not participating in hostilities, the targeting of peacekeepers is prohibited. ${ }^{71}$ Whether the entire mission becomes a party to the conflict or whether peacekeepers would lose their protection as non-combatants individually has been debated elsewhere. ${ }^{72}$ Regardless of this issue, the UN Security Council needs to be aware of the consequences of undertaking direct operations which open UN forces to lawful attack and risk embroiling the UN in a protracted conflict that could further harm civilians. ${ }^{73}$ If the 'robust turn' in peacekeeping is here to stay the UN will need to be proactive in clarifying the legal position of its peacekeepers when hostilities intensify and when UN forces are called upon to engage armed groups. Especially given the trend of stabilization missions cooperating closely with the host state there needs to be clear legal guidance from the UN Office of Legal Affairs on what types and levels of support can amount to UN participation in an armed conflict.

\subsection{Counter-Terrorism}

In September 2014 the UN Security Council adopted Resolution 2178 which condemned violent extremism, which can be conducive to terrorism, and called on states to do more to counter this threat. ${ }^{74}$ As part of the UN's response, the

\footnotetext{
71 ICRC, Customary IHL Database, Rule 33, https://ihl-databases.icrc.org/customary-ihl/eng/docs/v1_ rul_rule33; Rome Statute of the International Criminal Court, Art. 8(b)(iii).

72 Mathias (2017); ICRC (n. 67), p. 25.

73 Similar conclusions are reached by a recent Saferworld report where the UN uses more proactive force. Larry Attree, Jordan Street and Luca Venchiarutti, 'United Nations peace operations in complex environments: Charting the right course' (Saferworld, September 2018), https://www.saferworld.org.uk/ resources/publications/1183-united-nations-peace-operations-in-complex-environments-charting-theright-course, p. 29; Mona Ali Kahlil, 'The world needs robust peacekeeping not aggressive peacekeeping' (ICRC, 15 May 2018), https://blogs.icrc.org/law-and-policy/2018/05/15/world-needs-robust-peace keeping-not-aggressive-peacekeeping/.

74 UN Security Council, Resolution 2178 (24 September 2014), S/RES/2178.
} 
Secretary-General presented a Plan of Action to Prevent Violent Extremism to the General Assembly in January 2016. ${ }^{75}$ Karlsrud argues the Plan of Action forms part of a broad counter-terrorism agenda at the UN and gives it global legitimacy. ${ }^{76}$ As a result, the UN is pressured to conduct counter-terrorism activities but thus far has largely resisted. ${ }^{77}$ The HIPPO Report clearly states that UN missions should not conduct counter-terrorism operations and where the UN operates alongside parallel counter-terror forces the roles of each presence must be clearly demarcated. ${ }^{78}$ Though in 2017 the UN General Assembly established a UN Office of Counter-Terrorism to provide leadership on counter-terrorism mandates entrusted to the Secretary-General, strengthen UN counter-terrorism assistance, and improve the visibility of UN counter-terrorism efforts. ${ }^{79}$ As will be discussed below, the expansion and enhanced visibility of UN counter-terrorism activities pose a serious risk to a peace operation's other priority tasks.

The rhetoric of terrorism is no more present than in MINUSMA. The UN forces operate alongside French troops deployed as part of Operation Barkhane (previously Operation Serval) and a regional counter-terrorism force, the G-5 Sahel Force (FCG5S) ${ }^{80}$ Both the French and FC-G5S are said to support MINUSMA and the UN Security Council welcomed 'the continued action by the French forces [...] to deter the terrorist threat in the North of Mali' ${ }^{81}$ Furthermore, the UN Security Council stated the FC-G5S will 'facilitate the fulfilment by MINUSMA of its mandate to stabilize Mali'. ${ }^{82}$ In February 2018 a technical agreement was signed for MINUSMA to provide operational and logistical support to FC-G5S. ${ }^{83}$ During 2018 uniformed MINUSMA personnel assisted FC-G5S with preparing their operational bases and the Secretary-General called for coordination between the forces to be boosted further. ${ }^{84}$

MINUSMA has also supported the host state in its fight against terrorism. Mali has called for the UN Security Council to help Government forces in countering terrorism by deploying a Force Intervention Brigade, similar to that in MONUSCO,

\footnotetext{
75 UN General Assembly, 'Plan of Action to Prevent Violent Extremism' (24 December 2015), $\mathrm{A} / 70 / 674$.

76 Karlsrud (2019), p. 4.

77 See e.g. UN Security Council, 7355th Meeting (6 January 2015), S/PV.7355, p. 5 as per Mr. Diop; Charbonneau (2017), p. 421.

78 HIPPO Report (n. 5), p. 34; see also, Gray (2016).

79 UN General Assembly, 'Strengthening the capability of the United Nations system to assist Member States in implementing the United Nations Global Counter-Terrorism Strategy' (15 June 2017), A/ RES/71/291.

80 The UN Security Council welcomed FC-G5S in Resolution 2359 and provided for its formal cooperation with MINUSMA in Resolution 2391; for more information on the French intervention in Mali see Bannelier and Christakis (2018). UN Security Council, Resolution 2359 (21 June 2017), S/RES/2359; UN Security Council, Resolution 2391 (8 December 2017), S/RES/2391.

${ }^{81}$ UN Security Council, Resolution 2227 (19 June 2015), S/RES/2227, p. 3.

82 S/RES/2391 (n. 80), para. 12.

${ }^{83}$ UN Security Council, 'Joint Force of the Group of Five for the Sahel' (12 November 2018), S/2018/1006, para. 44.

${ }^{84}$ UN Security Council, 'Joint Force of the Group of Five for the Sahel' (8 May 2018), S/2018/432, paras. 3, 68 .
} 
to offensively combat terrorist groups. ${ }^{85}$ The UN Security Council has thus far refused to authorise such a force but MINUSMA has assisted the host state in putting its specialized unit on terrorism and transnational organized crime into action and helped with the drafting of a national counter-terrorism strategy. ${ }^{86}$ Charbonneau reports that a Malian official stated the 'UN should do its job and break these terrorists' ${ }^{87}$ One issue the UN faces when cooperating on terrorism is that the Malian authorities refer to the entire conflict, since 2012, as terrorism and does not distinguish between Tuareg rebel armed groups seeking self-determination and Islamic terrorists operating in the country. ${ }^{88}$

The UN Security Council is far from in agreement over the extent to which the UN should be involved with offensive counter-terrorism operations. Resolution 2359 does not authorise FC-G5S under Chapter VII, instead the regional force operates with the consent of the states involved, due to US reluctance. ${ }^{89}$ Neither has the UN Security Council previously used Chapter VII to authorise force against terrorists and instead states typically use force in self-defence. ${ }^{90}$ MINUSMA is an interesting situation though. MINUSMA is mandated to use robust force under Chapter VII and to provide logistical and operational support to FC-G5S and share intelligence. ${ }^{91}$ MINUSMA's Chapter VII mandate is consequently linked to supporting a regional counter-terrorism operation which uses offensive force with the open encouragement of the UN Security Council. By using UN resources to support the FC-G5S the UN Security Council is taking further steps to combat terrorism as a threat to international peace and security.

\subsubsection{Intelligence Sharing}

MINUSMA supports counter-terrorism through the identification of groups and individuals considered a threat to the mission and includes them in targeting packs. ${ }^{92}$ MINUSMA has a sophisticated intelligence system making use of a German unmanned aerial vehicle (UAV) unit and a Swedish reconnaissance company of armoured vehicles, amongst others. ${ }^{93}$ The targeting packs are compiled by the All Sources Information Fusion Unit (ASIFU) which is tasked with collecting actionable intelligence and has included personnel from the Netherlands, Sweden, and

\footnotetext{
${ }^{85}$ S/PV.7355 (n. 77), p. 5 as per Mr. Diop; UN Security Council, 7600th Meeting (11 January 2016), S/ PV.7600, p. 8 as per Mr. Diop.

$86 \mathrm{~S} / 2016 / 819$ (n. 41), para. 33.

87 Charbonneau (2017), p. 421.

${ }^{88}$ UN Security Council, 7719th Meeting (16 June 2016), S/PV.7719, p. 4 as per Mr. Keita; Charbonneau (2017), p. 421.

${ }^{89}$ Jennifer G Cooke, 'Understanding the G5 Sahel Joint Force: Fighting Terror, Building Regional Security?' (Center for Strategic and International Studies, 15 November 2017), https://www.csis.org/analysis/ understanding-g5-sahel-joint-force-fighting-terror-building-regional-security.

90 White (2012), pp. 73, 74; Henderson (2013) p. 157.

91 S/RES/2423 (n. 18), paras. 48, 50.

92 Karlsrud (2019), p. 13.

93 De Cherisey (2017) pp. 2, 3.
} 
Norway. ${ }^{94}$ The informal sharing of the targeting packs with Operation Barkhane was reported to the UN as possibly having 'serious operational, political and legal implications. ${ }^{95}$ The legal implication being, MINUSMA becomes a party to the conflict under IHL as a result of providing 'actionable intelligence' for the French Operation Barkhane. ${ }^{96}$ The HIPPO Report's determination that a UN peace operation should maintain clear and distinct divisions of labour between itself and parallel offensive operations has not been heeded in Mali. Where MINUSMA is concerned the divisions are blurred with ASIFU involving itself with the work of non-UN forces fighting terrorism.

Intelligence sharing between MINUSMA and FC-G5S could have a range of consequences both in law and for the individuals involved on the ground. States need effective legal systems to be able to address any human rights violations and to ensure the rule of law during counter-terror operations. ${ }^{97}$ Intelligence sharing in particular can affect a range of rights, such as the right to a private and family life or freedom of speech. The UN though does not have a legal system or frameworks in place to provide remedies for potential violations. The quagmire of holding the UN accountable has been extensively researched showing how difficult it is for individuals to hold international organisations accountable for their decisions when harm is caused. ${ }^{98}$ For the UN to continue its public engagement in intelligence sharing, at a minimum, a complaints system offering remedies and reparations will need to be available for affected individuals.

For example, human intelligence (HUMINT) is conducted through the cooperation of individuals to provide information. If MINUSMA is collecting intelligence from individuals, then it needs to be made overtly clear to individuals that the information will be shared with both MDSF and international forces. Collecting HUMINT requires trust from the individuals in the collecting body. ${ }^{99}$ Similarly, any signals intelligence, where data on individuals is mined, should have clear rules, be subject to independent oversight, and should be made explicit to individuals affected. ${ }^{100}$ To safeguard work on local peace initiatives the UN needs to make certain that possible negative outcomes and perceptions of intelligence sharing do not damage trust with local people. Individuals may feel aggrieved if information shared with the UN leads to human rights abuses committed by, for instance, MDSF forces during counter-terror operations.

The UN does have a Conduct and Discipline Unit (CDU) which receives allegations of misconduct, can make recommendations, and ultimately forward

\footnotetext{
94 Kjeksrud and Vermeij (2017), p. 232.

95 Karlsrud (2019), p. 13; The author cites UN, 'Lessons Learned Report' (Sources Information Fusion Unit and the MINUSMA Intelligence Architecture, Semi-final draft for USG Ladsous' review, 1 March 2016), p. 3. On file with John Karlsrud.

96 Karlsrud (2017b), p. 1224.

97 Staberock (2012), p. 357.

98 Freedman (2018), p. 962.

99 Staberock (2012), p. 361.

100 Ibid., p. 365.
} 
investigations to the Office of Internal Oversight Services (OIOS). ${ }^{101}$ The CDU has internal teams, Conduct and Discipline Teams (CDTs), within peace operations. MINUSMA's CDT emphasises its zero-tolerance policy on sexual exploitation and abuse. ${ }^{102}$ All UN staff must respect fundamental rights under the Staff Rules and Regulations, but this is far from a clear and incontrovertible framework for holding personnel responsible for violations arising from intelligence related activities. ${ }^{103}$ The issue of whether the UN would be able to exercise effective disciplinary authority for violations of rights in the course of intelligence gathering is further complicated by whether personnel are military or civilian, and if, in the absence of UN disciplinary authority, troop contributing countries (TCCs) would have the legal frameworks in place to address violations committed abroad while operating as part of the UN missions.

\subsubsection{Consequences of Engagement with Counter-Terror Operations}

The UN rightfully states the fight against terrorism must not infringe upon human rights or marginalise communities. ${ }^{104}$ The UN itself has recognised that Malian counter-terror operations have violated human rights law 'which compounded the communities' feeling of marginalization from the peace process'. ${ }^{105}$ In addition, the UN has already begun investigations into serious human rights violations committed by FC-G5S forces, including the killing of civilians. ${ }^{106}$ It is true that counterterror operations could create a more secure and stable environment by reducing the threat of terrorism. However, if, in the eyes of Malian communities, the UN is part of counter-terrorism efforts alongside the government and international forces which have committed numerous human rights violations the mission's efforts to bring together the affected parties and reconcile the conflict would be undermined. The UN's position as an impartial arbitrator would naturally be weakened.

As early as 2003, Bredel warned the UN should be cautious about allowing counter-terrorism to encroach unduly on the notion of long-term conflict prevention' ${ }^{107}$ Today MINUSMA risks damaging the creation of a lasting peace in Mali. For instance, Charbonneau highlights that Operation Barkhane and FC-G5S externalise the fight against terrorism by operating on a regional level and in turn undermine the Malian peace process. ${ }^{108}$ The mandates of the UN Security Council could cause further marginalisation in the north of Mali where they expressly support a counter-terrorism agenda and result in MINUSMA forces operating alongside FCG5S forces which have committed human rights violations. This would negatively

\footnotetext{
101 UN General Assembly, 'Comprehensive Review of the Whole Question of Peacekeeping Operations in All Their Aspects' (24 March 2005), A/59/710, para. 42; see e.g. Freedman (2018), p. 971.

102 MINUSMA, 'Conduct and Discipline', https://minusma.unmissions.org/en/conduct-and-discipline.

103 UN, 'Staff Rules Handbook', https://hr.un.org/handbook/staff-rules, Regulation 1.2.

104 UN Security Council, 'Report of the Secretary-General on the situation in Mali' (31 May 2016), S/2016/498, para. 84.

105 Ibid., para. 39.

106 S/2018/1006 (n. 83), para. 31.

107 Bredel (2003), p. 65.

108 Charbonneau (2017), pp. 424, 425.
} 
influence the peace process and further marginalisation would present a continued threat to international peace and security.

The UN's counter-terrorism agenda must be distinct from its other work if it wishes to avoid the risk of undermining other activities in pursuit of stabilization, such as inclusive peace and national reconciliation. Gowan believes the UN must be prepared to conduct robust operations to counter terrorism and if it does not it risks irrelevance. ${ }^{109}$ However, missions cannot work alongside offensive international forces if they realistically wish to assist with reconciling the differences of communities and groups which form the root causes of the conflict. A decision where the mission has gathered intelligence and designated certain persons as terrorists for targeting purposes could easily mar other mandated activities such as supporting local peace committees, for instance. The UN Security Council needs to utilise its mandating function to clarify in more detail a mission's role when it seeks to engage with counter-terrorism activities. A more transparent and clear approach to counter-terrorism is needed to demarcate what kinds of support UN forces are able to provide and importantly where the UN draws the line.

\subsection{Increased Cooperation with the Host State}

Cooperation with host state forces in stabilization missions presents a serious risk of partiality in the conflict. Following the Capstone Doctrine, it is understood that UN forces must be impartial in dealing with parties to the conflict but not neutral in the execution of the mandate and can take coercive action against spoilers, those who attempt to undermine the peace process. ${ }^{110}$ The position of the UN as an impartial actor becomes tenuous when the mandates of MINUSCA and MINUSMA expressly call for the missions to assist with the extension of state authority, assist with the redeployment of host state forces, and to conduct joint operations and share information. ${ }^{111}$ Kjeksrud and Vermeij argue MINUSMA has de facto partiality which has led to its forces being targeted for retaliation by armed and terrorist groups. ${ }^{112}$ By working alongside the host state the UN takes sides in a civil war and fails to act with any sense of impartiality. Where, in the eyes of individuals and communities, the UN cooperates with a state which has previously committed human rights violations the UN could lose the trust of sections of the population. For example, the UN has a visible commitment to ending conflict-based sexual violence and bringing perpetrators to justice, but that work could be threatened where the UN is seen to be synonymous with the perpetrators. Likewise, where communities are sympathetic to

\footnotetext{
109 Richard Gowan, 'The Downside of Keeping the U.N. Out of Counterterrorist Missions' (World Politics Review, 10 September 2018), https://www.worldpoliticsreview.com/articles/25829/the-downside-ofkeeping-the-u-n-out-of-counterterrorist-missions.

110 Capstone Doctrine (n. 45), p. 33; White (2015), p. 50.

111 See e.g. S/RES/2387 (n. 18), para. 42(a)(iv); S/RES/2364 (n. 18), para. 20(a)(i); UN Security Council, Resolution 2409 (27 March 2018), S/RES/2409, para. 34; S/RES/2423 (n. 18), para. 38(b).

112 Kjeksrud and Vermeij (2017), p. 234.
} 
the opposing side of the civil war the UN forces risk becoming the enemy alongside the host state potentially exacerbating the conflict.

Looking at the CAR specifically, a large number of FACA soldiers deserted following the 2012 coup and the Transitional Authorities sought assistance with rebuilding its military capabilities. The EU deployed a training mission (EUTM RCA) in 2016 to assist with defence sector reform. ${ }^{113}$ The EU has trained almost 3000 FACA soldiers who are now being redeployed to work alongside international forces. ${ }^{114}$ The UN stresses the members of FACA need "clean criminal and human rights records'. ${ }^{115}$ However, given the history of abuses by FACA it is paramount that communities trust the forces will not commit further human rights violations. ${ }^{116}$ MINUSCA has carried out joint patrols with FACA and supported their redeployment to Obo and Paoua on an $a d$ hoc and temporary basis. ${ }^{117}$ In the interim, while FACA regains the trust of the CAR people, the UN forces risk damaging their relationship with communities as the UN begins to cooperate more frequently with FACA forces.

One way to mitigate the risk of marginalisation is to explain the role of the UN's Human Rights Due Diligence Policy (HRDDP) to communities. The HRDDP requires that UN assistance can only be given to non-UN security forces upon their respect for human rights, humanitarian law, and refugee law. ${ }^{118}$ The policy is particularly relevant for stabilization operations due to the level of support given to the host state and UN cooperation with host state forces. The UN cannot provide support to or cooperate with forces where there are substantial grounds to believe violations could occur and corrective or mitigating measures have not been taken by the authorities in question. ${ }^{119}$ The HRDDP has been argued to go further than existing legal obligations by using a preventative mechanism to avoid situations where there is merely a risk of violations. ${ }^{120}$

\footnotetext{
${ }^{113}$ Council Decision (CFSP) 2016/1791 on the signing and conclusion, on behalf of the Union, of the Agreement in the form of an Exchange of Letters between the European Union and the Central African Republic on the status of the European Union CSDP Military Training Mission in the Central African Republic (EUTM RCA) [2016] OJ L274/31.

114 EUTM, 'European Union Training Mission in Central African Republic (EUTM-RCA)' (13 August 2018), https://eeas.europa.eu/sites/eeas/files/180823_mission_factsheet_eutm_rca_jul18_v1.pdf.

115 UN Security Council, 'Letter dated 15 May 2018 from the Secretary-General addressed to the President of the Security Council' (16 May 2018), S/2018/463, para. 22.

116 This issue is recognised by the UN here, S/2018/463 (n. 115), paras. 4, 25.

117 UN Security Council, 7787th Meeting (10 October 2016), S/PV.7787, p. 2 as per Mr. Ladsous; S/2018/463 (n. 115), para. 5.

118 UN Security Council, 'Report of the Secretary-General on the situation in Mali' (28 November 2012), S/2012/894, para. 22.

${ }^{119}$ UN General Assembly and Security Council, 'Identical letters dated 25 February 2013 from the Secretary-General addressed to the President of the General Assembly and to the President of the Security Council' (5 March 2013), UN Doc. A/67/775-S/2013/110, para. 1.

${ }^{120}$ Aust (2015), p. 71.
} 


\subsubsection{Responsibility for Internationally Wrongful Acts}

Support for the redeployment of MDSF and FACA could have legal consequences for the UN where host state forces commit serious breaches of human rights or humanitarian law. Most literature on the responsibility of peacekeepers for wrongful acts focuses on the apportioning of responsibility between the UN and TCCs. ${ }^{121} \mathrm{UN}$ forces are regularly deemed subsidiary organs and under Article 6 of the Draft Articles on Responsibility of International Organizations (DARIO) the UN is responsible for their wrongful conduct. Article 7 of DARIO also allows for responsibility to be allocated to whomever has effective control over the organ, which may be the UN or the TCC depending on who, at the time of the wrongful act, has command and control of the forces. ${ }^{122}$ However, the UN has stated it assumes responsibility under Article 6 for acts of UN forces as organs of the organisation regardless of whether there is effective control making Article 7 'almost entirely redundant'. ${ }^{123}$ Arguments have been made though that forces contributed by TCCs are not fully under the command and control of the UN and Article 7 and its effective control test is relevant. ${ }^{124}$ With increased cooperation between the UN and the host state, apportioning responsibility between the UN and host state forces may become increasingly relevant.

Would it then be possible to hold the UN responsible for actions committed by host state forces where the UN and host state have cooperated closely? First, looking at Article 7, the host state troops would need to be regarded as organs or agents of the UN. The UN has a tight definition of who is to be regarded as an agent of the organisation and has criticised the International Law Commission's broad use of the term 'agent' in DARIO. ${ }^{125}$ Even in a situation where host state forces are mandated to cooperate and carry out functions alongside UN forces the UN would still not automatically regard them as agents for attribution. There would need to be a degree of control of the host state forces by the UN mission's chain of command to be regarded as more than merely partners achieving a common goal. As a result, the actions of host state forces will only be attributable to the organisation under Article 7 if there is a 'sufficiently close relationship' or the UN has effective control over the forces. $^{126}$

Another route to find responsibility is Article 14 of DARIO. An international organisation can be held responsible where it 'aids or assists' a state in the commission of an internationally wrongful act if: (a) the organisation does so with

\footnotetext{
121 See e.g. Ryngaert (2012), Palchetti (2013) and Buchan (2012).

122 Draft Articles on Responsibility of International Organizations, with commentaries (2011), Art. 7.

123 UN General Assembly, 'Responsibility of international organizations: comments and observations received from international organizations' (17 February 2011), A/CN.4/637/Add.1, pp. 13, 14; Ryngaert (2012), p. 159.

124 Ryngaert (2012), p. 162; Buchan (2012) argues that neither the effective control or 'ultimate authority and control' tests are suitable.

125 Ryngaert (2012), p. 162.

126 Ibid., pp. 162, 163.
} 
knowledge of the circumstances of the internationally wrongful act; and (b) the act would be internationally wrongful if committed by that organisation. ${ }^{127}$ For UN responsibility its forces would need to make a 'significant' contribution to the wrongful act. ${ }^{128}$ An example of the risk arose in the UN Mission in the Democratic Republic of the Congo (MONUC) where the mission needed to decide whether to adhere to its mandate requiring it to provide support to host state forces who were likely to commit serious violations or refuse to do so. ${ }^{129}$ The UN Office of Legal Affairs decided that where there is reason to believe host states are engaged in serious violations then the UN forces cannot lawfully continue to provide support. ${ }^{130}$ Similarly, in 2014 the UN Security Council terminated assistance to the South Sudanese government provided by the UN Mission in South Sudan (UNMISS) after civil war broke out. ${ }^{131}$ Mathias says it is unclear how much support the UN would need to provide to be responsible for a wrongful act. ${ }^{132}$

This question is important today with the mandates of MINUSMA and MINUSCA expressly calling for support and cooperation between UN and host state forces. The situation with MONUC occurred before the inception of the HRDDP. The UN makes it clear any support given to a state is on the basis that the state respects human rights and humanitarian law. Stabilization practice in general though is geared toward the UN providing direct support to the state for extending the latter's authority. Despite the UN's insistence on adhering to the HRDDP it is true that both MINUSMA and MSDF forces have committed human rights abuses in recent years. If this becomes more prevalent, particularly alongside counter-terror operations, then the UN Office for Legal Affairs will need to evaluate whether UN stabilization missions can continue to provide support to their host states.

To mitigate any risk to other priorities in the mandate the UN Security Council could use the mandate to more clearly demarcate how and where assistance will be given and communicate this to the population. The use of radio to disseminate information and improve communication is included in MINUSMA's mandate but only since 2017 , over 4 years since the mission's initial authorisation. ${ }^{133}$ The UN Security Council must be more conscious of considering how best to disseminate mandates and their purpose to local populations and create a manageable set of expectations.

A commitment to the HRDDP is important from the start of a stabilization mission that will be cooperating closely with the host state. Karlsrud says the emphasis on the HRDDP shows there are 'lingering concerns' about close cooperation with other actors. ${ }^{134}$ The UN could conversely distance itself from the host state, not take sides in a civil war, and use the mandates to publicly spell out the distinction between UN and host state forces. This could help harmonise the two sides of

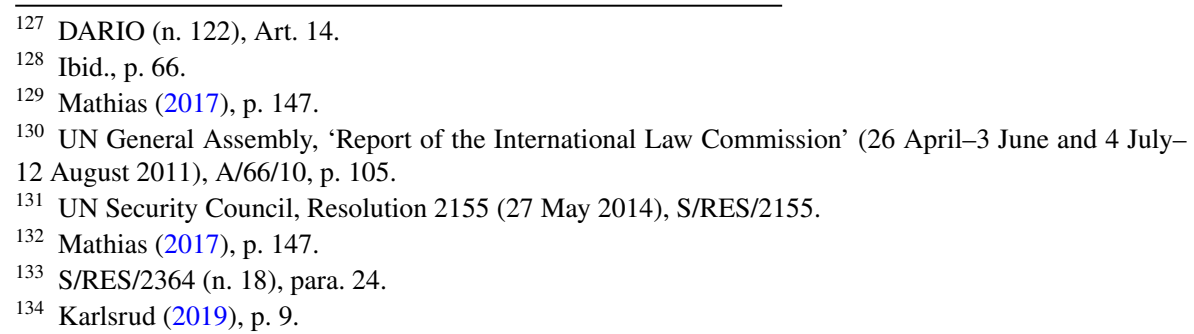


current stabilization practice and make sure that building the capacity and working with the host state does not compromise a mandate's other tasks. However, the organisation still needs to adopt a definition of stabilization to give a consistent foundation for mandates.

\subsection{Human Rights and the Rule of Law}

An area of stabilization practice perhaps not given enough attention by existing literature is the focus on ensuring the rule of law and ending impunity. Re-establishing the rule of law forms part of the second step of stabilization, peacebuilding in the power vacuum left behind after displacing armed groups. Peace operations achieve this by supporting the host state in rebuilding the criminal justice system through training judges, refurbishing courts and prisons, and in the case of MINUSCA, assisting with the creation of a Special Criminal Court under unique powers found in the mandate.

When MINUSCA was first mandated, the UN Security Council stressed the need to end impunity for violations of international law either within the national legal system or before the International Criminal Court. ${ }^{135}$ To assist the transitional authorities in that endeavour, MINUSCA was to monitor and report on violations of IHL and human rights and to work on preventing future violations by utilising human rights observers. ${ }^{136}$ Though ending impunity would be particularly difficult where the Central African authorities lacked sufficient control of government functions. MINUSCA was mandated to extend state authority, to build the capacity of the judicial system and reinstate the criminal justice system 'within the framework of the United Nations global focal point on rule of law'. ${ }^{137}$ This formed part of an overarching strategy for MINUSCA where it was believed (a) international forces would be more effective if the penal system was re-established and (b) there must be development and respect of human rights and the rule of law if the CAR is to have peace. ${ }^{138}$ To further rectify the 'dysfunctional' legal system in the CAR, MINUSCA adopted urgent temporary measures 'to maintain basic law and order and fight impunity' authorised under its mandate. ${ }^{139}$

Establishing law and order to support international justice and protect civilians is a unique aspect of MINUSCA's mandate. Under the mission's initial mandate, the UN Security Council decided,

\footnotetext{
135 UN Security Council, Resolution 2149 (10 April 2014), S/RES/2149, p. 2, para. 12.

136 Ibid., para. 30(e)(i).

137 Ibid., paras. 30(f)(ii), 30(f)(iii).

138 UN Security Council, 7206th Meeting (24 June 2014), S/PV.7206, p. 3 as per Mr. Gaye; UN Security Council, 'Report of the Secretary-General on the Central African Republic submitted pursuant to paragraph 48 of Security Council resolution 2127 (2013)' (3 March 2014), S/2014/142, para. 10.

139 UN Security Council, 'Letter dated 19 December 2014 from the Secretary-General addressed to the President of the Security Council' (22 December 2014), S/2014/928, para. 56; S/RES/2149 (n. 135), para. 40; S/RES/2301 (n. 18), para. 34(d)(i).
} 
...that MINUSCA may, within the limits of its capacities and areas of deployment, at the formal request of the Transitional Authorities and in areas where national security forces are not present or operational, adopt urgent temporary measures on an exceptional basis and without creating a precedent and without prejudice to the agreed principles of peacekeeping operations, which are limited in scope, time bound and consistent with the objectives set forth in paragraphs 30 (a) and 30 (f) above, to maintain basic law and order and fight impunity and requests the Secretary-General to report to the Security Council any measures that may be adopted on this basis. ${ }^{140}$

The temporary measures have been used to initiate the creation of a Special Criminal Court with international judges to try 'serious crimes, including serious violations of human rights and international humanitarian law, including conflict-related sexual violence as well as grave violations of the rights of the child, that constitute a threat to peace, stability or security'. ${ }^{141}$ Despite Russian criticism of the potential inefficiency and costliness of the Court, in June 2017 a Special Prosecutor and five judges were sworn in and in May 2018 the rules of procedure and evidence for the Court were adopted by the CAR parliament. ${ }^{142}$ The Court's first session was held in October 2018.

Similarly, since 2014 MINUSMA has undertaken training and quick impact projects (QIPs) to improve the rule of law including the rehabilitation of courts and training of judges, magistrates, and local government officials. ${ }^{143}$ Alongside this MINUSMA has understood that 'long-term reconciliation will not be possible without the promotion and defence of the human rights of all communities in the north'. ${ }^{144}$ The focus on human rights, both as a task to assist the Malian authorities with and as a monitoring and reporting task for the UN, has since been carried over into each renewal of MINUSMA's mandate. ${ }^{145}$ Issues in Mali remain however where, for example, large numbers of perpetrators of sexual violence are not prosecuted despite MINUSMA following up repeatedly with the Malian authorities. Similarly, the trial of the leader of the 2012 coup, General Sanogo, for complicity in the killing of 21 soldiers is yet to be completed after numerous delays.

\footnotetext{
${ }_{140}$ S/RES/2149 (n. 135), para. 40.

${ }^{141}$ UN Security Council, 'Letter dated 19 December 2014 from the Secretary-General addressed to the President of the Security Council' (22 December 2014), S/2014/928, para. 63.

${ }^{142}$ UN Security Council, 7901st Meeting (16 March 2017), S/PV.7901, p. 11 as per Mr. Iliichev; Human Rights Watch, 'Central African Republic: Parliament Adopts Special Criminal Court Rules' (4 June 2018), https://www.hrw.org/news/2018/06/04/central-african-republic-parliament-adopts-special-crimi nal-court-rules.

${ }^{143}$ S/2014/403 (n. 38), para. 28; UN Security Council, 7864th Meeting (18 January 2017), S/PV.7864, p. 9 as per Mr. Diop; UN Security Council, 'Report of the Secretary-General on the Situation in Mali' (23 December 2014), S/2014/692, para. 24; UN Security Council, 'Report of the Secretary-General on the Situation in Mali' (28 September 2017), S/2017/811, para. 59.

${ }^{144}$ UN Security Council, 'Report of the Secretary-General on the situation in Mali' (10 June 2013), S/2013/338, para. 82 .

${ }^{145}$ S/RES/2227 (n. 81), para. 14(e); S/RES/2295 (n. 39), para. 19(f); S/RES/2364 (n. 18), para. 20(f).
} 
The work of MINUSCA and MINUSMA on human rights and extending the rule of law forms a crucial part of the UN's emerging stabilization practice. Particularly in the CAR the UN has taken up the mantle of revitalising the justice system in the wake of widespread human rights abuses and sexual violence perpetrated throughout the conflict. The mandate specifies the temporary measures used to establish the Special Criminal Court are used without establishing precedent. ${ }^{146}$ If the Court is effective the use of similar measures in future mandates could prove desirable as part of a stabilization strategy. Ending impunity is a way in which the UN Security Council can link the work of peace operations to wider agendas on international criminal justice and universal human rights. A focus on the rule of law and ending impunity could be a positive step for UN peace operations where missions can tap into the UN's rich expertise in the area. However, if the UN wishes to continue this strategy the UN Security Council will need to pay close attention to the outcome of the approach taken in the CAR. It is important to note again that in Mali the MDSF have committed human rights violations during its counter-terror activities undermining work on the rule of law. ${ }^{147}$ In addition, detainees have also been released in an effort to reconcile differences, but some have questioned whether the justice system is credible. The UN will need to balance its support for the host state and counter-terror activities alongside its work on the rule of law and human rights to ensure the two areas are not in conflict.

\section{Conclusion}

This article has outlined a picture of what UN stabilization mandates include despite the UN Security Council not being sufficiently clear. The resulting strategy of clearing an area of armed groups through the use of robust force to extend state authority and building peace in the vacuum left behind is not without its risks. It has been argued that the robust use of force in defence of the mandate strays into taking the initiative in the use of force and currently toes a fine line between peacekeeping and peace enforcement. Furthermore, taking the initiative could lead to the intensification of hostilities and ultimately the UN could be regarded as a party to the conflict under IHL. In the future, the UN Security Council will need to clarify its use of the term 'robust' and the UN should provide legal guidance on the consequences of robust force and support for the host state.

In the current climate, counter-terrorism is a hot topic which demands the UN's attention. It is important that the UN responds to current needs to be as relevant as possible and at the moment that means having a response to global terrorism. However, it is suggested that if the UN Security Council wishes to engage further with counter-terrorism operations the UN will need to be cautious about supporting the activities of other international and regional operations and the effect the support has on competing pursuits, such as supporting national reconciliation. Operating alongside the host state is becoming a principal feature of stabilization and

${ }_{146}$ S/RES/2149 (n. 135), para. 40; S/RES/2301 (n. 18), para. 34(d)(i).

147 S/2016/498 (n. 104), para. 39. 
poses similar risks as counter-terrorism. Depending on the level of support provided the UN exposes itself to legal responsibility for wrongful acts committed by the host state. A documented consequence of the host state violating human rights, for instance, is that the population feels marginalised from the peace process. The situation in Mali in particular needs to be monitored closely with future research examining the effect of counter-terror efforts on the Malian peace process.

The thread which links the issues discussed above is how the UN will ensure harmony between the first stage of stabilization and the second. Under current practice competing interests in the mission mandates risk undermining each other. The focus of the missions above on the rule of law and using local-level peace initiatives to foster national reconciliation are positive developments in the mandating of operations. However, the UN will need to carefully consider how it wishes to proceed in future stabilization mandates to avoid a situation where fighting terrorists or working closely alongside the state frustrates efforts to build an inclusive peace. Particularly in international law, the effects of these new mandates which include robust force and counter-terror cooperation are underexplored. Stabilization mandates will need further attention from international lawyers in the coming years if the UN continues along its current plotted course.

Acknowledgements I am grateful for invaluable feedback from Dr. Ioannis Kalpouzos, Dr. Mauro Barelli, Dr. David Curran, and Dr. Machiko Kanetake.

Open Access This article is distributed under the terms of the Creative Commons Attribution 4.0 International License (http://creativecommons.org/licenses/by/4.0/), which permits unrestricted use, distribution, and reproduction in any medium, provided you give appropriate credit to the original author(s) and the source, provide a link to the Creative Commons license, and indicate if changes were made.

\section{References}

Aust H (2015) The UN human rights due diligence policy: an effective mechanism against complicity of peacekeeping forces? J Confl Secur Law 20(1):61-73

Bannelier K, Christakis T (2018) The intervention of France and African countries in Mali-2013. In: Ruys T, Corten O, Hofer A (eds) The use of force in international law: a case-based approach. Oxford University Press, Oxford, pp 812-827

Bellamy A, Hunt C (2015) Twenty-first century UN peace operations: protection, force and the changing security environment. Int Aff 91(6):1277-1298

Berdal M (2018) The state of UN peacekeeping: lessons from Congo. J Strateg Stud 41(5):721-750

Boutellis A (2015) Can the UN stabilize Mali? Towards a UN stabilization doctrine? Stab Int J Secur Dev 4(1):1-16

Bredel R (2003) The UN's long-term conflict prevention strategies and the impact of counter-terrorism. Int Peacekeep 10(2):51-70

Buchan R (2012) UN peacekeeping operations: when can unlawful acts committed by peacekeeping forces be attributed to the UN. Legal Stud 32(2):282-301

Charbonneau B (2017) Intervention in Mali: building peace between peacekeeping and counterterrorism. J Contemp Afr Stud 35(4):415-431

Curran D, Holtom P (2015) Resonating, rejecting, reinterpreting: mapping the stabilization discourse in the United Nations Security Council, 2000-2014. Stab Int J Secur Dev 4(1):1-18

de Cherisey E (2017) Desert watchers: MINUSMA's intelligence capabilities. Jane's Def Wkly 54(23):1-13 
de Coning C (2015) Offensive and stabilization mandates. In: Peter M (ed) United Nations peace operations: aligning principles and practice. NUPI Report No. 2. NUPI, Oslo, pp 17-18

de Coning C (2017) Peace enforcement in Africa: doctrinal distinctions between the African Union and United Nations. Contemp Secur Policy 38(1):145-160

de Coning C (2018) Is stabilization the new normal? Implications of stabilization mandates for the use of force in UN peacekeeping operations. In: Nadin P (ed) the use of force in UN peacekeeping. Routledge, London, pp 85-99

Foley C (2017) UN peacekeeping operations and the protection of civilians. Cambridge University Press, Cambridge

Freedman R (2018) UNaccountable: a new approach to peacekeepers and sexual abuse. Eur J Int Law 29(3):961-985

Gerchicoff B (2013) Keeping Capstone in context: evaluating the peacekeeping doctrine. Strateg Anal 37(6):729-741

Gill T, Fleck D (2015) Peace operations. In: Gill T, Fleck D (eds) The handbook of the international law of military operations, 2nd edn. Oxford University Press, Oxford, pp 153-184

Gill T, Fleck D, Boothby W, Vanheusden A (eds) (2017) Leuven manual on the law applicable to peace operations. Cambridge University Press, Cambridge

Gordon S (2010) The United Kingdom's stabilisation model and Afghanistan: the impact on humanitarian actors. Disasters 34(S3):S368-S387

Gray C (2016) The 2015 report on uniting our strengths for peace: a new framework for UN peacekeeping? Chinese JIL 15(1):193-213

Henderson C (2013) The centrality of the United Nations Security Council in the legal regime governing the use of force. In: White N, Henderson C (eds) Research handbook on international conflict and security law. Edward Elgar, Cheltenham, pp 120-169

Karlsrud J (2015) The UN at war: examining the consequences of peace-enforcement mandates for the UN peacekeeping operations in the CAR, the DRC and Mali. Third World Q 36(1):40-54

Karlsrud J (2017a) The UN at war: peace operations in a new era. Palgrave Macmillan, London

Karlsrud J (2017b) Towards UN counter-terrorism operations? Third World Q 38(6):1215-1231

Karlsrud J (2019) From liberal peacebuilding to stabilization and counterterrorism. Int Peacekeep 26:1-21

Kjeksrud S, Vermeij L (2017) Protecting governments from insurgencies: the Democratic Republic of the Congo and Mali. In: de Coning C, Aoi C, Karlsrud J (eds) UN peacekeeping in a new era. Routledge, London, pp 227-245

Mac Ginty R (2012) Against stabilization. Stab Int J Secur Dev 1(1):20-30

Mathias S (2017) UN peacekeeping today: legal challenges and uncertainties. Melb J Int Law 18(2):138-153

Murphy R (2007) UN peacekeeping in Lebanon, Somalia and Kosovo. Cambridge University Press, Cambridge

Pacholska M (2015) (Il)legality of killing peacekeepers: the crime of attacking peacekeepers in the jurisprudence of international criminal tribunals. J Int Crim Justice 13(1):43-72

Palchetti P (2013) The allocation of responsibility for internationally wrongful acts committed in the course of multinational operations. Int Rev Red Cross 95(891/892):727-742

Peter M (2015) Between doctrine and practice: the UN peacekeeping dilemma. Glob Gov 21(3):351-370

Ryngaert C (2012) Apportioning responsibility between the UN and member states in UN peace-support operations - an inquiry into the application of the 'effective control' standard after Behrami. Isr Law Rev 45(1):151-178

Sloan J (2018) UN peacekeeping and international law. In: Nadin P (ed) The use of force in UN peacekeeping. Routledge, London, pp 265-291

Staberock G (2012) Intelligence and counter-terrorism. In: Salinas de Frías A, Samuel K, White N (eds) Counter-terrorism: international law and practice. Oxford University Press, Oxford, pp 351-387

Tardy T (2011) A critique of robust peacekeeping in contemporary peace operations. Int Peacekeep $18(2): 152-167$

Tull D (2018) The limits and unintended consequences of UN peace enforcement: the Force Intervention Brigade in the DR Congo. Int Peacekeep 25(2):167-190

White N (2012) The United Nations and counter-terrorism. In: Salinas de Frías A, Samuel K, White N (eds) Counter-terrorism: international law and practice. Oxford University Press, Oxford, pp 54-82 
White N (2015) Peacekeeping and international law. In: Koops J, MacQueen N, Tardy T, Williams P (eds) The Oxford handbook of United Nations peacekeeping operations. Oxford University Press, Oxford, pp 43-59

Publisher's Note Springer Nature remains neutral with regard to jurisdictional claims in published maps and institutional affiliations. 